\title{
THE ECONOMIC BALANCE OF THE CZECH REPUBLIC AND SLOVAKIA DURING THE ECONOMIC CRISIS
}

\author{
llya Bolotov, Radek Čajka, Kateřina Gajdušková*
}

\begin{abstract}
:
The paper examines development of economic balance and efficiency of monetary and fiscal policy in the Czech Republic and Slovakia during the crisis with the help of empirical verification of Robert Mundell's model of effective market classification. Our main findings show that although there was no direct 'loser' during the crisis, the Czech Republic seemed to have better coped with its economic imbalances due to the independence of its monetary policy. Slovakia, on the contrary, has preserved several problems on the side of external balance. However, as both countries show certain differences, it is impossible to assess whether the euro adoption had the same effect on both of them. In general, the paper contributes to the research on the Czech and Slovak economy and euro area membership.
\end{abstract}

Keywords: internal balance, external balance, economic crisis, effective market classification model, cointegration analysis, error correction model

JEL Classification: C22, E30, E63, F41

\section{Introduction}

Both the Czech and the Slovak economies have experienced their fastest development since the beginning of the new century and a relatively important decline during the global crisis. The structure of both economies is very similar, with above average share of industry, which arises from the long industrial tradition and inflow of direct investment in this field. Both economies are often being described as open. Slovakia is more open - $81 \%$ to GDP (average value of exports and imports of goods and services in 2010) compared to $77 \%$ to GDP in case of the Czech Republic (own calculations based on Eurostat data). However, there are several differences. Firstly, their starting positions were different. In 2000, the Czech Republic reached $68 \%$ of EU27 GDP level (in PPS), while Slovakia took only $50 \%$ (Eurostat data). Secondly, Slovakia became member of the euro area in 2009 and gave up its independency in monetary policy. The question therefore arises, whether both countries cope with the current crisis in the same way.

The aim of our paper is to examine the development of economic balance and the efficiency of monetary and fiscal policy in the Czech Republic and Slovakia during the crisis.

* Kateřina Gajdušková (katerinagajduskova@gmail.com), Radek Čajka (radek.cajka@vse.cz), Ilya Bolotov (ilya.bolotov@vse.cz), University of Economics, Prague, W. Churchill Sq. 4, CZ - 13067 Prague 3. This paper was elaborated within the UEP IGS Project No. F2/15/2010. 
The paper is divided into two main parts. In the first part we briefly compare the economic balance of the two countries for the years 2000-2010 with emphasis on the global crisis. The second part is based on Robert Mundell's model of effective market classification, EMC (Mundell, 1962 and 1968; Mandel, 2000; and Mandel and Tomsik, 2001 and 2003) as a theoretical reference of attaining balance through fiscal and monetary policy. Its empirical verification is compared with measures used in both countries during the crisis. Based on this comparison, we conclude which country was more efficient in solving its problems.

In total, the paper fills the gap in comparison of macroeconomic performance of the Czech and Slovak economies during the crisis and helps to assess the impact of the euro area membership during the crisis. Its value added also constitutes an empirical verification of the EMC model in both countries for the new century.

\section{Internal and External Balance of the Countries before and during the Crisis}

According to the theory (Pilbeam, 2006, p. 70), the economic balance of a country consists of two interconnected balances - internal and external. The Oxford Dictionary of Economics (Black, 2003) gives the following definition of the internal balance: "A situation where the level of activity in an economy is consistent with a stable rate of inflation. At higher activity levels inflation tends to rise, and at lower levels unemployment is unnecessarily high." The external balance is then "A sustainable pattern of transactions with the rest of the world. With no capital movements, in a static economy external balance requires a zero balance of payments on current account, since otherwise foreign exchange reserves would become exhausted if there was a current account deficit, and would expand without limit if there was a current account surplus. " (Black, 2003). In practice, however, small current account deficits (up to 5\% of GDP) are still tolerated.

In economic literature, e.g. Mandel (2000) and Mandel and Tomsik (2001 and 2003), the external balance of small open economies usually also includes foreign direct investment (long-term capital), as it constitutes the source of financing of their current account deficits in the long run.

The recent research on the internal and external balance of the Czech Republic and Slovakia was conducted by Lazovy and Slovakova (2009); Coudert and Pouvelle (2010); Gajduskova (2010a and 2010b); Cajka (2010a, 2010b and 2010c); Bolotov (2011) and Cajka, Gajduskova and Bolotov (2011) by the Czech National Bank, e.g. Singer (2010) and Slovak Academy of Sciences, e.g. Radvansky, M. (2010).

\subsection{Internal balance}

From the perspective of the internal balance, the Czech Republic and Slovakia were affected by the crisis less significantly, compared to the other EU New Member States (NMS). The reason was their relatively low private debt (the share of credit in GDP 
of around $40-45 \%$ and sustainable credit growth rates before the crisis; Coudert and Pouvelle, 2010) together with an important inflow of foreign direct investment (5-7\% of GDP in the long run), which led to higher stability of the Czech and Slovak economies during the crisis.

Therefore the impact of the financial crisis on their internal balance was caused primarily by external factors: the decrease in foreign demand (values of export constitute $70-80 \%$ of GDP in both countries) and in foreign direct investment inflows (for more details on the impact of the crisis on the internal balance of the NMS, see Bolotov, 2011).

To compare the changes in the internal balance of the Czech Republic and Slovakia graphically we use a modified version of the so-called 'magic square' model. ${ }^{1}$ The square shows a country's current economic situation presented with the help of four main indicators: gross domestic product growth rate $(\mathrm{g})$, inflation rate ( $\pi$, consumer prices), unemployment rate (U) and government deficit (GD) expressed as a percentage of the GDP. ${ }^{2}$ The zero points are placed on the axis in such manner, so that the size and shape of the magic square reflect the well-being of the country: bigger and more proportional quadrangles reflect positive situations, while smaller and disproportional ones show economic problems.

Figure 1 compares the economic situation in the Czech Republic and Slovakia before the crisis (the average values of the period 2000-2007) and during the years 2008 and 2009.

It can be seen that the Czech Republic showed greater stability, but lower economic growth than Slovakia (the difference was 1-3 percentage points) most of the time except the year 2008 when it experienced higher inflation (6.3\% compared to $3.9 \%)$ and bigger government deficit (-2.7\% of GDP compared to $-2.1 \%)$. Structural government deficits and unemployment (up to $16.5 \%$ in average in Slovakia) were, in general, characteristic for both countries before the crisis and partly in 2008 .

Comparing this development to the euro area (Maastricht) convergence criteria, which can be also regarded as an indicator of the EU members' stability, the performance of both economies was improving before the crisis, allowing Slovakia to adopt the euro in 2009.

However, in the first year of the crisis (2009) both economies were placed under the Excessive Deficit Procedure (EDP), as they experienced an important deterioration of the government deficit (-5.9\% and $-8 \%$ of GDP, far below the criterion of $-3 \%$ ) caused by a severe contraction in GDP of more than $4 \%$.

1 Some sources attribute the invention of the 'magic square' to Karl Schiller, the German Federal Minister of Economic Affairs and, later, of Finance; others - to the Cambridge economist Nicholas Kaldor.

2 Government deficit is here defined as net lending (+) / net borrowing (-) under the Excessive Deficit Procedure (EDP). Public finance stability became a discussed topic after the emergence of the European debt crisis (2010) and speculations about the default on payments of the U.S. government (2011). For the Czech Republic and Slovakia, it also forms part of the Maastricht (the euro area) convergence criteria. 
Figure 1

Magic Squares before and during the Crisis (\%)
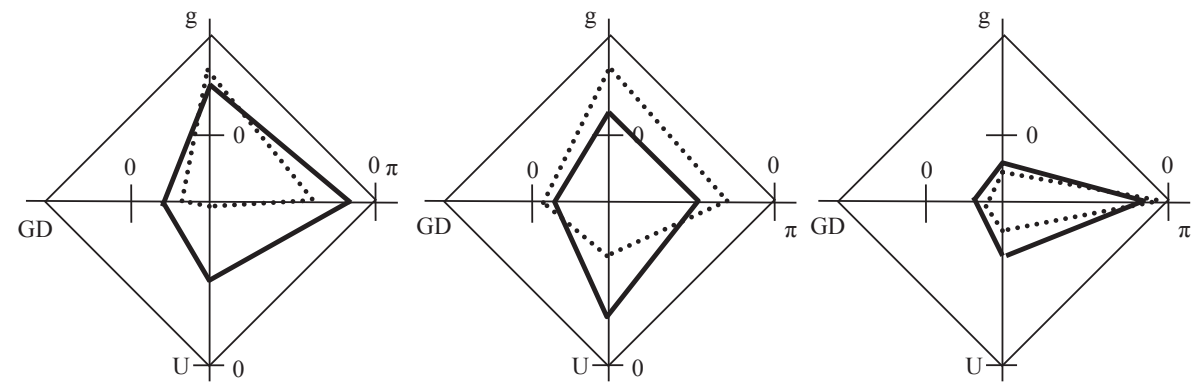

Czech Republic

Slovakia

\begin{tabular}{|c|c|c|c|c|c|c|c|c|c|c|c|c|c|c|c|c|}
\hline & \multicolumn{4}{|c|}{ 2000-2007 } & \multicolumn{4}{|c|}{2008} & \multicolumn{4}{|c|}{2009} & \multicolumn{4}{|c|}{2010} \\
\hline & g & $\pi$ & U & GD & g & $\pi$ & $\mathbf{U}$ & GD & g & $\pi$ & U & GD & g & $\pi$ & U & GD \\
\hline Czech Rep. & 4.1 & 1.8 & 7.6 & -4.1 & 2.5 & 6.3 & 4.4 & -2.7 & -4.1 & 0.6 & 6.7 & -5.9 & 2.7 & 1.2 & 7.3 & -4.7 \\
\hline Slovakia & 4.9 & 5.1 & 16.5 & -5.0 & 6.2 & 3.9 & 9.6 & -2.1 & -4.8 & 0.9 & 12.1 & -8.0 & 4.2 & 0.7 & 14.4 & -7.9 \\
\hline
\end{tabular}

Notes: The year 2010 constitutes the recovery phase, therefore it is not shown on the graph.

Source: Czech Statistical Office, Slovstat Database, Eurostat; calculations by the author.

One of the reasons for this deterioration was the implementation of fiscal packages across countries to stimulate national economies. In Slovakia, the net effect amounted to $-1.4 \%$ of GDP consisting of $0.7 \%$ cuts in taxes and $0.7 \%$ additional spending measures. In the Czech Republic, the net effect amounted to $-2.8 \%$ of GDP, consisting of $2.5 \%$ cuts in taxes and $0.3 \%$ additional spending measures (OECD, 2010, p. 275).

\subsection{External balance}

The economic and financial crisis also affected the external balance. It brought about a change in the current account and financial account structure (see Table 1). Deficits of trade balances (net exports - NX) within current accounts disappeared and turned into surpluses (Slovakia) or surpluses rose (Czech Republic). This was caused by higher drop in the value of imports than exports (for further details on this topic see Cajka, 2010c). Income balances (IB) also changed during the period. In both countries the deficits were gradually increasing (mainly because investment income expenditures; the role of compensation of employees is not significant) till 2007 , which was directly connected to good performance of enterprises owned by non-residents who were transferring profits to parent companies located abroad. With the economic slowdown, also the companies had realized lower profits, which turned into lower value of investment income expenditures. This development can be seen in 2008 in both countries (compared to 2007) and in 2009 in Slovakia, where this trend was prolonged based on negative internal balance development (see above). 
Table 1

Main Accounts of Balance of Payments before and during the Crisis

\begin{tabular}{|l|c|c|c|c|c|c|c|c|c|c|c|c|}
\hline & \multicolumn{3}{|c|}{$2000-2007$} & \multicolumn{3}{c|}{2008} & \multicolumn{3}{c|}{2009} & \multicolumn{3}{c|}{2010} \\
\cline { 2 - 15 } & NX & IB & FDI & NX & IB & FDI & NX & IB & FDI & NX & IB & FDI \\
\hline Czech Rep. & -29.9 & -134 & 171.8 & 67.2 & -174 & 36.3 & 149.6 & -249 & 37.7 & 121.2 & -254 & 97.0 \\
\hline Slovakia & -1.7 & -1.7 & 3.3 & -0.8 & -1.9 & 2.9 & 0.9 & -0.9 & -0.7 & 0.8 & -1.2 & 0.1 \\
\hline
\end{tabular}

Notes: In billion CZK (Czech Rep.), billion EUR (Slovakia)

Source: Czech Statistical Office, Czech National Bank, Slovstat Database, Eurostat, Slovak National Bank; calculations by author.

Net inflow of foreign direct investment also dropped during the crisis and has not recovered yet. Here the decrease showed the largest extent as investors lost investment appetite in uncertain economic environment. In 2008 the decrease was higher in the Czech Republic than in Slovakia, but in the following years Slovakia experienced even more serious decline. For further details on this topic see Gajduskova (2010b) or Cajka, Gajduskova and Bolotov (2011).

The financial crisis has led to a deeper external imbalance in both economies, when negative income balances (despite the fact that their deficits declined to some extent) could not have been totally financed with non-debt foreign capital. The decrease in foreign direct investment had impact not only on the worsening of external imbalance, but it also influenced the internal balance in a negative way. That is because foreign investment takes a considerable part in the employment in CEE countries and in times of economic crisis, when foreign companies are restraining their new investment or decreasing the activity in other countries, subsidiary companies have to lay off many employees.

In general the growth of export of the Czech economy shows higher stability than in the case of the Slovak economy. This also applies to the period of the beginning of economic crisis. The export dropped in case of Slovakia during 2008 almost to its two thirds of the export of the previous year, whereas in case of the Czech economy the year to year decrease amounted only to about $20 \%$. Throughout 2009 and 2010 , as both economies had been recovering from their biggest downturn, value of their exports tended to rise. First ten months of 2009 were more successful for the Czech economy, on the other hand last two months of 2009 and 2010 accounted for higher export growth rate in Slovakia. By mentioning this, we should also turn our attention to the exchange rate development in both countries. There is a dispute about the role of the pegged value of the Slovak currency to euro, namely whether there was negative influence on the value of exports (due to currency overvaluation together with depreciating other currencies in the region) or almost no influence. It is not the aim of this paper that is why we let this issue without any strong statement.

To sum up the development of internal and external balance, we can state that both countries under study have had to cope with different problems in their balances. Internal 
balance in the case of the Czech Republic remains more stable (with the exception of 2008, when the development was caused mainly by internal factors in the Czech Republic and Slovakia was on its way to enter the Eurozone), but at the expense of lower economic growth. Slovakia still has to cope with higher unemployment rate and government deficit.

External balance can be described in similar way. The problem is how to finance current account deficit (or specifically income balance deficit). Trade balance surpluses are not large enough and the net inflow of FDI has decreased considerably. This problem concerns more Slovakia, since the incoming FDI is on minimum level and with economic upturn further deterioration of income balance is expected.

\section{Fiscal and Monetary Policy of the Countries during the Crisis}

In this part of the paper, we will examine how the imbalances caused by the crisis were solved by the both countries' policy makers. For this purpose we use the Robert Mundell's model of the effective market classification, EMC (1962 and 1968), adjusted by Mandel (2000) and Mandel, Tomsik (2001 and 2003) to small open transitional economies with floating exchange rates, and with a modification for the years 2000-2010 tested in Cajka, Gajduskova and Bolotov (2011). The model, in compliance with the Tinbergen's principle (number of instruments corresponding to the number of policy targets), searches for the right combination of fiscal and monetary policy measures to ensure internal and external balance of a country.

The main idea of the EMC model is that both policies influence the external and internal balance. Therefore, in order to be efficient, they should not follow the same goal and should be "paired with the objectives on which they have the most influence" (the so-called principle of effective market classification; Mundell, 1962, p. 483, and 1968, p. 239). Otherwise, the efforts of the government and the central bank may worsen the existing economic problems or lead to cyclical instability (Pilbeam, 2006, p. 93).

The model works with two main variables: firstly it is a budget deficit / surplus, T-G (originally tax revenues minus government expenditures), which represents the fiscal policy, and secondly it is the interest rate, IR, which represents the monetary policy. Certain combinations of T-G and IR form a schedule of the internal (line XX) and external balance (line FF). ${ }^{3}$ Changes in the country's monetary and fiscal policies are then interpreted with changes of the schedules.

3 In the original model, both schedules have a negative slope and the FF schedule is steeper than the $\mathrm{XX}$ making the monetary policy more efficient for the external balance and fiscal policy for the internal balance (comparing the necessary changes in IR and in T-G). The reason lies in the higher reaction of capital flows to interest rate changes and in the fixed exchange rate. This, however, may not be valid for modified versions of the model. 
Mundell (1962), however, developed his model only in verbal terms and under several assumptions $^{4}$ (see Mandel, 2000, p. 6 and Pilbeam, 2006, p. 95-96). Therefore we base our analysis on the cited works of Mandel and Tomsik who relaxed some of them, mainly the fixed exchange rate and the influence of real values, and performed several empirical verifications of the model for the Czech economy for the years 1993-2000.

\subsection{Econometric representation of the modified EMC model}

According to both the original and the modified version of the model, the internal balance is a situation when the country's aggregate expenditure / demand (domestic demand plus net exports) equals the gross domestic product at full employment (potential product), which can be formally written as

$$
\mathrm{AE}=\mathrm{A}_{\mathrm{DOM}}+\mathrm{NX}=\mathrm{Y}_{\mathrm{POT}}, \quad N X=E X-I M \Leftrightarrow \mathrm{Y}_{\mathrm{POT}}-\mathrm{A}_{\mathrm{DOM}}-(\mathrm{EX}-\mathrm{IM})=0
$$

where $Y_{\text {POT }}$ - potential product, $A_{D O M}$ - demand for domestic output, $A E$ - aggregate expenditure, NX - net exports of goods and services.

The external balance equation corresponds to the country's balance of payments and depends on the type of country. For small open market economies like the Czech Republic and Slovakia, which are dependent on foreign direct investment inflows and which have a limited borrowing capacity, Mandel (2000) and Mandel and Tomsik (2001 and 2003) propose the so-called "non-debt financing of current account deficits" balance, ND:"

$$
\mathrm{ND}=\mathrm{NX}+\mathrm{FDI}=0, \quad N X=E X-I M
$$

where NX - net exports and FDI - net foreign direct investment.

However, in 2000-2010 both the Czech and Slovak economies began to experience growing income balance deficits resulting from inflows of foreign direct investment (mainly due to revenue, interest and dividends paid to direct investors) and, less significantly, from immigration (for the Czech Republic see e.g. Plchova, 2006), ${ }^{6}$ which increases the risk of capital outflow during the crisis. Therefore, we extend the external balance equation to

4 These assumptions excluded the influence of exchange rate movements and risk premiums, the impact of capital imports on domestic expenditure, the reaction of capital indebtedness to the changes in the interest rate, strong "Pigou" (real wealth, i.e. real money supply) effects, speculation on international markets related to the country's fiscal situation and forward rate movements changing the interest rate differential. Some of these assumptions corresponded to the reality of the 1960s, e.g. fixed exchange rates in the Bretton Woods system.

5 Mandel and Tomsik, however, mention that this definition also has its drawbacks. According to the national accounting standards, some capital transactions are recorded only on the financial account making $\mathrm{NX}+\mathrm{FDI}>0$. The other problem represents the growing deficit of the income balance in the CEE countries; solved below.

6 Mainly in the case of the Czech Republic which experiences immigration of workers from the EU member states, Eastern Europe and some other countries. In the case of Slovakia immigration is less important. 


$$
N D^{*}=E X-I M+I B+F D I=0
$$

where IB is the income balance.

The functional relationships between the variables in the model can then be written in the following way for both the Czech Republic and Slovakia, ${ }^{7}$ as defined by Mundell (1962), Mandel and Tomsik (2001 and 2003) and Cajka, Gajduskova and Bolotov $(2011):^{8}$

$$
\begin{aligned}
& A_{D O M}=\alpha_{0}+\alpha_{1}(T-G)+\alpha_{2} I R_{C P I}+\alpha_{3} M 2_{C P I}+\alpha_{4} Y, \\
& E X=\beta_{0}+\beta_{1} E R_{C P I}+\beta_{2} Y_{E U}, \\
& I M=\gamma_{0}+{ }_{o} \gamma(T-G)+\gamma 2 I R_{C P I}+\gamma_{3} M 2_{C P I}+\gamma_{4} E R_{C P I}+\gamma_{5} E X, \\
& I B=\chi_{0}+\chi_{1} F D I_{\text {stock }}, \\
& F D I=\eta_{0}+\eta_{1} I R_{C P I}+\eta_{2} Y+\eta_{3} U \\
& E R=\omega_{0}+\omega_{1} I R_{C P I}
\end{aligned}
$$

where

$I R_{C P I}$ - real 3-month interbank offering rate (deflated by consumer price index, CPI);

$M 2_{C P I}$ - real money supply (intermediate money, deflated by CPI);

$E R_{C P I}$ - real average exchange rate, EUR and USD weighted by the EU 27 and non-EU 27 share in the country's external trade (SKK/EUR is held for 30.126 beginning from $1^{\text {st }}$ January 2009 , deflated by CPI);

$Y_{E U} \quad$ - real gross domestic product of the EU 27 minus the country's GDP (deflated by the EU 27's Harmonized Index of Consumer Prices, HICP);

$F D I_{\text {stock }}$ - stock of foreign direct investment;

$U \quad$ - unemployment rate;

$Y \quad-$ real gross domestic product of the examined country;

$E X \quad-$ exports of goods and services;

IM - imports of goods and services;

According to the economic theory, see e.g. Pilbeam (2006),

$$
\alpha_{1}, \alpha_{2}, \gamma_{1}, \gamma_{2}, \gamma_{4}, \chi_{1}, \chi_{2}, \eta_{1},{ }^{9} \omega_{1}<0 \text { and } \alpha_{3}, \alpha_{4}, \beta_{1}, \beta_{2}, \gamma_{3}, \gamma_{5}, \eta_{2}, \eta_{3}>0 \text {. }
$$

7 Due to the similarities between the two economies and the fact that the model is not dependent on the size of the country, we apply the same equations to both cases.

8 The authors attempt to combine both the monetary and Keynesian theoretical approaches using several real variables in the internal and external balance equations (real money supply, real interest rate, real exchange rate and real gross domestic product), therefore losing some of the original assumptions. Exports and imports are also analyzed separately in order to obtain more precise results than in the case of net exports.

9 Mandel and Tomsik mention that foreign direct investment is usually less sensitive to interest rate changes; and when investors finance their investment through loans in the local currency (which is common in the NMS thanks to a developed banking sector), FDI can be indirectly related to them. Therefore, we can expect $\eta 1<0$. 
To increase the quality of regression estimates, we also perform several 'robustness checks' adding regressors to the equations (4) - (9). The additional variables are selected according to prior empirical research on the topic and to their theoretical relevance for the Czech and the Slovak economies: CPL (Comparative price level with USA $=100 \%$ ), LOC (economic location), ${ }^{10} \mathrm{TF}$ (the Heritage Foundation's trade freedom index), $F D I_{\text {stock, } t-1}$ (FDI stock of the previous period), ${ }^{11} I R_{E A, H I C P}$ (the real interest rate of the euro area, deflated by the EU 27's HICP), a dummy variable for the membership in the European Union (starting from 2nd quarter 2004) and in the euro area for Slovakia (starting from 1st quarter 2009) and a dummy variable for the global recession (4th quarter 2008 - 4th quarter 2009). ${ }^{12}$

For the research on the topic, see e.g. Tomsik (2000), Vagac, Palenik et al. (2001a and 2001b), Guttman and Richards (2004), Kral (2004), Hsing (2005), Ghosh (2007), Jankovic and Yatrakis (2011), Cerna (2011) and Havrlant and Husek (2011).

Based on the regression results, we then calculate the slopes of the XX and FF lines (the external and internal balance equations), under the condition of ceteris paribus, ${ }^{13}$ with the help of the following formulas:

XX schedule:

$$
T-G={\overline{A_{1}}}^{\prime}-\frac{\alpha_{2}+\beta_{1} \omega_{1}}{\alpha_{1}} I R_{C P I}
$$

FF schedule:

$$
T-G={\overline{A_{2}}}^{\prime}-\frac{\left(\gamma_{2}-\eta_{1}\right)+\left(-\beta_{1}+\gamma_{4}+\gamma_{5} \beta_{1}\right) \omega_{1}}{\gamma_{1}} I R_{C P I}
$$

where ${\overline{A_{1}}}_{1}^{\prime}$ and $\bar{A}_{2}^{\prime}$ are autonomous parts, i.e. interceptions with the T-G axis on a corresponding graph.

\subsection{Data and methodology}

For the empirical verification of the model, we used quarterly data for the period 1st quarter 2000 - 1st quarter 2011 (45 observations) from the official statistical sources: the Czech and Slovak statistical offices and central banks, Eurostat and the European Central Bank (for $I R_{E A, H I C P}$ ), French Institute for International Economic Relations, CEPII, and the World Bank including data on the GDP of Taiwan (for LOC), Penn World tables (for CPL) and the Heritage Foundation (for TF). Missing values

10 We calculate LOC as a weighted average of the shortest Great World Cycle (on the globe) distances between the capitals of the Czech Republic and Slovakia and main cities (capitals or main economic centers) of all their possible trading partners, i.e. rest of the world, where the shares of each partner in the rest of the world's GDP are taken as weights. Changes in LOC then indicate changes in the countries' position in the world economy.

11 The lag represents the time needed for the both economies to absorb investment, here one quarter.

12 The European debt crisis due to its seemingly lesser significant effect on both economies was not included.

13 All variables except the (T-G) and IR are considered to be constant and form part of ${\overline{A_{1}}}_{1}$ and ${\overline{A_{2}}}_{2}$. 
were extrapolated ${ }^{14}$ and yearly data disaggregated into quarterly observations using Chow and Lin's procedure (1971).

The model was processed with the help of single equation co-integration analysis, according to Engle and Granger (1987), Arlt (1997) and Dougherty (2006). White's standard errors (the $\mathrm{HC} 0$ method) were used to remove eventual heteroscedasticity and Cochrane-Orcutt (a general least squares, GLS) method, according to Cochrane and Orcutt (1949), to remove autocorrelation, AR (1), of residuals. ${ }^{15}$

\subsection{Empirical results}

All variables were integrated of order 1 according to augmented Dickey-Fuller (ADF) tests and to the graphical analysis of autocorrelation functions. The same analysis found the existence of long-term relationships in all equations (some were, however, weak). The results of regression models after the robustness checks, corresponding error-correction models and mutual correlation of variables are presented in appendices 1 and 2 .

In total, the quality of the models measured by adjusted R-squared was relatively good (greater than 0.5) with the exception of IB and FDI equations (ca. 0.33-0.30 and ca. $0.15-0.13$ ). The overview of the coefficients not meeting the assumption at significance level of 0.1 and their comparison with correlation coefficients is presented in Table 2.

Table 2

Coefficient Values not Meeting the Theoretical Assumptions

\begin{tabular}{|c|c|c|c|c|c|c|c|c|c|c|c|}
\hline \multirow[b]{2}{*}{ Result / Assumption } & \multicolumn{2}{|c|}{$A_{\text {DOM }}$} & \multirow{2}{*}{\begin{tabular}{|c|} 
EX \\
$\mathbf{b}_{1}>\mathbf{0}$ \\
$E R_{C P I}$ \\
\end{tabular}} & \multicolumn{4}{|c|}{ IM } & \multicolumn{3}{|c|}{ FDI } & \multirow{2}{*}{$\begin{array}{c}\mathrm{ER}_{\mathrm{CPI}} \\
\mathbf{w}_{1}<0 \\
\mathrm{IR}_{\mathrm{CPI}}\end{array}$} \\
\hline & $\begin{array}{l}a_{1}<0 \\
(T-G)\end{array}$ & $\begin{array}{l}a_{3}>0 \\
M 2_{C P I}\end{array}$ & & $\begin{array}{l}\mathbf{g}_{1}<0 \\
(T-G)\end{array}$ & $\begin{array}{l}\mathbf{g}_{2}<0 \\
\mathrm{IR}_{\mathrm{CPI}}\end{array}$ & $\begin{array}{l}\mathbf{g}_{3}>\mathbf{0} \\
M 2_{C P I}\end{array}$ & $\begin{array}{l}\mathbf{g}_{4}<\mathbf{0} \\
E R_{\mathrm{CPI}}\end{array}$ & $\begin{array}{l}\mathrm{n}_{1}<0 \\
\mathrm{IR}_{\mathrm{CPI}}\end{array}$ & $\begin{array}{c}\mathbf{n}_{2}>\mathbf{0} \\
Y\end{array}$ & $\begin{array}{c}\mathbf{n}_{3}>\mathbf{0} \\
U\end{array}$ & \\
\hline \multicolumn{12}{|c|}{ Czech Republic } \\
\hline Regression coeff. & n.s. & $-0,172$ & n.s. & OK & n.s. & n.s. & n.s. & OK & n.s. & -0.020 & n.s. \\
\hline Correlation coeff. & -0.215 & -0.069 & -0.928 & OK & -0.615 & 0.888 & -0.910 & OK & -0.269 & 0.155 & 0.744 \\
\hline \multicolumn{12}{|c|}{ Slovakia } \\
\hline Regression coeff. & 0.535 & n.s. & n.s. & n.s. & OK & n.s. & $1 e-4$ & $1 e-4$ & OK & n.s. & n.s. \\
\hline Correlation coeff. & -0.283 & 0.422 & -0.925 & -0.104 & OK & 0.868 & $-0,908$ & 0.236 & OK & -0.023 & 0.948 \\
\hline
\end{tabular}

Notes: Statistically insignificant values are marked as "n.s.".

Source: Appendices 1 and 2; calculations by the author.

It can be seen that in several cases, the sign of the regression coefficient corresponded to the correlation coefficient between the dependent and independent variables: $a_{3}$ for

14 Extrapolation was performed in the case of $\mathrm{FDI}_{\text {stock, } \mathrm{t}-1}$, ImPOP and $\mathrm{M} 2_{\mathrm{CPI}}$ time series. AR(1), $\mathrm{AR}(2)$, ARMA and autocorrelation-adjusted time series regression models were used for this purpose.

15 This combination provided better results than the Newey-West standard errors (the HAC estimator). 
the Czech Republic and $n_{l}$ for Slovakia. The opposite results to the assumption and correlation coefficients were reached for coefficients $n_{3}$ for the Czech Republic and $a_{1}$ and $g_{4}$ for Slovakia.

The non-significance of some coefficients, however, remains unexplained, as in their case correlation is mostly in accordance with our assumptions. ${ }^{16}$ The IM, ER and FDI equations are therefore the least successful in the model. The other 'problematic' coefficients may be considered as less important, as in their case the correlation is weak.

The possible reasons for the described deviations of the empirical results from the theoretical assumptions may be the following:

- The model was designed to describe the countries' situation in the 1990s: some relations could have changed in the past 10 years.

- The relationships inside the model may be non-linear, e.g. log-linear.

- The model lacks dynamics despite the usage of the Cochrane-Orcutt GLS method. For example, time lag for similar export and import functions were used in Tomsik (2000) and Vagac, Paleniketali (2001b).

- More than 45 observations could be needed to obtain more precise results.

Despite the mentioned problems, we can calculate the slopes of XX and FF schedules from the results.

Czech Republic XX: $T-G=\bar{A}_{1}^{\prime}-0.003774 I R_{C P I}$,

Slovakia XX: $T-G={\overline{B_{1}}}^{\prime}-0.06206 I R_{C P I,} \quad F F: I R_{C P I}={\overline{B_{2}}}^{\prime}$

Where $\overline{B_{1}}{ }^{\prime}$ and $\overline{B_{2}}{ }^{\prime}$ are modified $\overline{A_{1}}{ }^{\prime}$ and $\bar{A}_{2}^{\prime}$

\subsection{Graphical interpretation of the results}

Figure 2 depicts the XX and FF schedules for the Czech Republic and Slovakia. In reality, countries have to face limitations imposed by the European Union (the Maastricht convergence criteria): the floor of $-3 \%$ of GDP for $T-G$ (the fiscal criterion, F.C.) and the ceiling of 2 percentage points above the average of the three lowest inflation EU countries for $I R_{C P I}$ (the monetary criterion, M.C.). Therefore we add two dashed lines to both graphs.

The graph of the Czech Republic has a relatively regular shape. According to the findings of Mandel and Tomsik (2001), the FF schedule also had a positive slope in the Czech Republic in 1990s due to the floating exchange rate and a negative

16 The results also showed unexpected signs for the EU and euro area membership dummies in most equations. However, as these variables are additional, their detailed analysis is left for future studies on the topic. 
correlation between $F D I$ and $I R_{C P I}$. The XX schedule has a traditional negative slope. Fiscal policy is therefore inefficient for installing the internal balance: monetary policy should be the best solution for internal imbalances and fiscal policy for external ones. This also corresponds to the findings of Mandel and Tomsik (2001).

\section{Figure 2}

\section{Graphical Representation of the EMC Model for Both Countries}
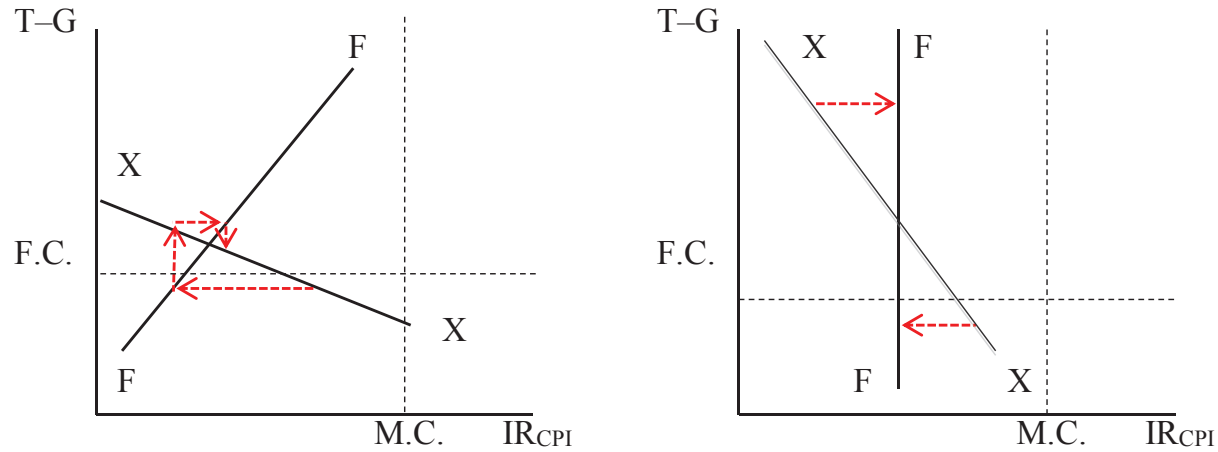

Notes: Zero point $\left(T-G=0\right.$ and $\left.I R_{C P I}=0\right)$ is above F.C. on the vertical axis.

Source: calculations by the author.

Points to the right of the schedules indicate recession and external deficit, as the real interest rates are too high; and points to the left of the schedules indicate internal and external surpluses. To get out of the recession (e.g. a crisis), the country thus needs to adjust its $I R_{C P I}$, and $T-G$ consequently, in a manner of a cobweb, until it reaches the point of equilibrium, i.e. interception of the schedules.

Table 3

Economic Balance Indicators and Fiscal and Monetary Policy, Czech Republic

\begin{tabular}{|c|c|c|c|c|c|c|c|c|c|c|c|c|}
\hline & \multicolumn{4}{|c|}{2008} & \multicolumn{4}{|c|}{2009} & \multicolumn{4}{|c|}{2010} \\
\hline & Q1 & Q1 & Q3 & Q4 & Q1 & Q1 & Q3 & Q4 & Q1 & Q1 & Q3 & Q4 \\
\hline \multicolumn{13}{|c|}{ Internal balance } \\
\hline g $\%$ & -4.86 & 7.28 & -0.48 & -1.72 & -8.05 & 5.57 & -0.44 & 0.44 & -4.17 & 7.38 & -1.05 & 1.12 \\
\hline $\mathrm{U}, \%$ & 4.70 & 4.21 & 4.27 & 4.38 & 5.77 & 6.33 & 7.29 & 7.25 & 8.05 & 7.13 & 7.09 & 6.87 \\
\hline \multicolumn{13}{|c|}{ External balance } \\
\hline ND*, $\%$ of GDP & 3.72 & 0.22 & 2.09 & -2.38 & 3.31 & -3.36 & -4.09 & 2.81 & 6.20 & -0.29 & -0.33 & -3.50 \\
\hline \multicolumn{13}{|c|}{ Measures } \\
\hline T-G, $\%$ of GDP & -3.82 & -1.05 & 0.49 & -7.35 & -6.51 & -2.47 & -7.26 & -9.55 & -5.95 & -1.03 & -5.60 & -7.54 \\
\hline $\mathrm{IR}_{\mathrm{CPI}}, \%$ & 3.48 & 3.61 & 3.37 & 3.58 & 2.30 & 1.94 & 1.64 & 1.48 & 1.21 & 1.03 & 0.96 & 0.94 \\
\hline
\end{tabular}

Notes: ND* and T-G are presented \% of GDP.

Source: Cointegration regression data; calculations by the author. 
According to Table 3, the strategy was implemented in practice in the Czech Republic during the current crisis (changes $T-G$ and $I R_{C P I}$ were more or less alternated). Beginning from the end of the year 2009 the equilibrium was approached (lower decreases of real GDP, reduction in unemployment, external surpluses). However, $T-G$ below ca. $-7 \%$ of GDP seemed to produce significant external imbalances, which means that the economy moved below the interception of the schedules.

The possible problem of the Czech Republic is then the risk that the equilibrium point is located below the F.C. line and not as depicted on the graph, which means that the current structure of the economy (for which structural budget deficits are necessary) ${ }^{17}$ may cause long-lasting debt problems. Public finance reforms are therefore necessary in order to achieve stable development and to be able to fulfill the Maastricht convergence criteria.

The graph of Slovakia is more irregular: the FF schedule is vertical due to the positive correlation between $T-G$ and demand for domestic output and weak correlation between $T-G$ and import. Fiscal policy is thus efficient for Slovakia's internal balance and monetary policy for its external balance, which corresponds to the original Mundell's assumptions.

Points to the right of the schedules then also indicate recession and external deficit and points to the left of the schedules indicate internal and external surpluses. To get out of the recession (= crisis), the country thus needs to lower its $I R_{C P I}$, and increase (or, in some cases, decrease) $T-G$.

Table 4

Economic Balance Indicators and Fiscal and Monetary Policy, Slovakia

\begin{tabular}{|c|c|c|c|c|c|c|c|c|c|c|c|c|}
\hline & \multicolumn{4}{|c|}{2008} & \multicolumn{4}{|c|}{2009} & \multicolumn{4}{|c|}{2010} \\
\hline & Q1 & Q1 & Q3 & Q4 & Q1 & Q1 & Q3 & Q4 & Q1 & Q1 & Q3 & Q4 \\
\hline \multicolumn{13}{|c|}{ Internal balance } \\
\hline g \% & -10.18 & 8.91 & 7.24 & -3.38 & -15.92 & 8.59 & 7.67 & -1.98 & -8.68 & 8.11 & 7.30 & -2.34 \\
\hline U, \% & 10.50 & 10.10 & 9.00 & 8.70 & 10.50 & 11.30 & 12.50 & 13.90 & 15.10 & 14.40 & 14.10 & 13.90 \\
\hline \multicolumn{13}{|c|}{ External balance } \\
\hline ND*, $\%$ of GDP & -1.30 & -9.04 & 1.29 & 4.77 & -5.11 & -6.80 & -2.23 & -0.60 & -0.13 & \begin{tabular}{|l|}
-1.55 \\
\end{tabular} & -6.80 & -3.68 \\
\hline \multicolumn{13}{|c|}{ Measures } \\
\hline T-G, \% of GDP & -2.32 & -2.01 & -0.15 & -5.61 & -6.04 & -9.35 & -7.45 & $\mid-14.44$ & -7.38 & -8.69 & -6.11 & -14.89 \\
\hline $\mathrm{IR}_{\mathrm{CPI}}, \%$ & 3.85 & 3.81 & 3.79 & 3.22 & 1.69 & 1.07 & 0.68 & 0.54 & 0.49 & 0.51 & 0.67 & 0.79 \\
\hline
\end{tabular}

Notes: ND* and T-G are presented \% of GDP.

Source: Cointegration regression data; calculations by the author.

According to Table 4, the decrease in the real interest rates performed by the European Central Bank (ECB) together with a decrease in $T-G$ seemed to have solved the internal imbalances in Slovakia in 2010 (lower fall in GDP and small reduction in

17 For example, the average $\mathrm{T}-\mathrm{G}$ before the crisis (2000-2007) was ca. $-4.6 \%$ of GDP. 
unemployment). The external balance was, however, not attained during the entire period (with two exceptions), although greatly reduced in 2010 , when the $I R_{C P I}$ reached ca. 0.5 . This points to the fact that the interest rates were still too high. ${ }^{18}$

Thus, the main problem of Slovakia is often the inability to achieve its external balance given by the fact that fiscal policy is in its case inefficient and the monetary policy is now determined by the ECB.

To conclude, the EMC model in both countries shows certain similarities, mainly the shape of the XX schedule. However, the Czech Republic seemed to have better coped with the crisis due to the ability to control its monetary policy. Nevertheless, as the shapes of the model are different, it is impossible to assess whether the membership in the euro area would have had the same effect in both countries if it had been adopted at the same time.

\section{Conclusion}

The aim of our paper was to examine the development of economic balance and the efficiency of monetary and fiscal policy in the Czech Republic and Slovakia during the crisis. Based on the data, it is possible to state that each country did better than the other one in some aspects, but there was no direct "winner" during the crisis. Moreover, the year 2010 showed signs of economic recovery and return to the long-term tendencies: both countries showed positive growth of gross domestic product of more than $2 \%$, and the Slovak economy grew nearly twice as fast as the Czech one (4.2\% against $2.7 \%$ ). However, Slovakia has shown higher unemployment rate, higher government deficit, slightly lesser stability of export growth, and more importantly, higher decrease in net foreign direct investment. This leads us to the statement that both internal and external balance of the Czech Republic has been less influenced since the beginning of the crisis.

According to the empirical verification of the model of effective market classification, EMC, based on co-integration regression analysis corrected for heteroscedasticity and autocorrelation, fiscal policy seems to be inefficient in Slovakia for restoring its external balance. Therefore, as the Czech Republic has control over both of its fiscal and monetary policies, it seems to have better coped with the global crisis attaining economic equilibrium at least for some period of time. The country's main problem, however, remains the risk that this equilibrium is connected to relatively important structural budget deficits (greater than the Maastricht fiscal criterion). Slovakia, on the contrary, has preserved external imbalances due to its dependence on the European Central bank monetary policy. These theoretical conclusions correspond to the development of macroeconomic indicators from the examined period.

Nevertheless, as the shapes of EMC the model are different for both countries, we cannot conclude that the eventual membership in the euro area had had the same effect on the Czech Republic as well.

18 In general, reduction in the real interest rates seems to have always produced improvement of the external balance in the examined time period. 


\section{Appendix 1}

Regression Results for the Czech Republic

\begin{tabular}{|c|c|c|c|c|}
\hline C-O estimation (GLS) & Coeff. & S.E. & \multicolumn{2}{|c|}{ p-value } \\
\hline \multicolumn{5}{|c|}{ Dependent variable: Adom } \\
\hline const & 0.10372 & 0.07396 & 0.1692 & \\
\hline (T-G) & 0.19652 & 0.12813 & 0.1336 & \\
\hline IRcpi & -0.0109 & 0.00637 & 0.0939 & * \\
\hline M2cpi & -0.1721 & 0.04138 & 0.0002 & $* * *$ \\
\hline $\mathbf{Y}$ & 0.73114 & 0.14951 & $1.98 \mathrm{e}-05$ & $* * *$ \\
\hline EU dummy & -0.0614 & 0.02018 & 0.0043 & $* * *$ \\
\hline Crisis dummy & 0.10204 & 0.01752 & $1.08 \mathrm{e}-06$ & *** \\
\hline \multicolumn{3}{|l|}{$F=9.106137$} & $3.94 \mathrm{e}-06$ & $* * *$ \\
\hline \multicolumn{5}{|c|}{ Adjusted R-squared = 0.782797} \\
\hline \multicolumn{5}{|l|}{$D-W=1.781411$} \\
\hline \multicolumn{5}{|c|}{ Dependent variable: EX } \\
\hline const & -1.2236 & 0.51819 & 0.0239 & * \\
\hline ERcpi & 0.00206 & 0.00435 & 0.6375 & \\
\hline Yeu & 0.29632 & 0.04521 & $1.45 \mathrm{e}-07$ & *** \\
\hline FDlstock. t-1 & -0.0414 & 0.10253 & 0.6885 & \\
\hline CPL & 0.86536 & 0.40055 & 0.0377 & ** \\
\hline LOC & 0.00008 & 91.0 e-6 & 0.3511 & \\
\hline EU dummy & 0.06884 & 0.02205 & 0.0036 & $* \star *$ \\
\hline Crisis dummy & -0.0584 & 0.01610 & 0.0009 & *** \\
\hline \multicolumn{3}{|l|}{$F=24.43198$} & $1.06 \mathrm{e}-11$ & *** \\
\hline \multicolumn{5}{|c|}{ Adjusted R-squared $=0.980555$} \\
\hline \multicolumn{5}{|l|}{$D-W=1.763483$} \\
\hline \multicolumn{5}{|c|}{ Dependent variable: IM } \\
\hline const & 0.503574 & 0.177015 & 0.0076 & *** \\
\hline (T-G) & -0.17565 & 0.102423 & 0.0957 & * \\
\hline IRcpi & 0.001341 & 0.006160 & 0.8290 & \\
\hline M2cpi & 0.092305 & 0.056422 & 0.1113 & \\
\hline ERcpi & 0.000966 & 0.002718 & 0.7245 & \\
\hline EX & 0.986940 & 0.099309 & $1.89 \mathrm{e}-11$ & *** \\
\hline CPL & -0.09475 & 0.262454 & 0.7204 & \\
\hline LOC & -0.00005 & 0.000032 & 0.1792 & \\
\hline TF & -0.51475 & 0.158464 & 0.0027 & *** \\
\hline U dummy & -0.01315 & 0.012657 & 0.3061 & \\
\hline Crisis dummy & -0.01475 & 0.014964 & 0.3316 & \\
\hline \multicolumn{3}{|l|}{$F=248.4090$} & $4.48 \mathrm{e}-28$ & *** \\
\hline \multicolumn{5}{|c|}{ Adjusted R-squared $=0.988641$} \\
\hline \multicolumn{5}{|l|}{$D-W=1.906035$} \\
\hline
\end{tabular}


(Continuation)

\begin{tabular}{|c|c|c|c|c|}
\hline \multicolumn{5}{|c|}{ Dependent variable: IB } \\
\hline C-O estimation (GLS) & Coeff. & S.E. & \multicolumn{2}{|c|}{ p-value } \\
\hline const & -0.0026 & 0.00974 & 0.7922 & \\
\hline FDlstock & -0.0207 & 0.00856 & 0.0206 & ** \\
\hline EU dummy & -0.0092 & 0.00886 & 0.3045 & \\
\hline Crisis dummy & 0.00068 & 0.00964 & 0.9441 & \\
\hline \multicolumn{3}{|l|}{$F=10.40705$} & 3.4 e- 07 & $* * *$ \\
\hline \multicolumn{5}{|c|}{ Adjusted R-squared $=0.333450$} \\
\hline \multicolumn{5}{|l|}{$D-W=2.010504$} \\
\hline \multicolumn{5}{|c|}{ Dependent variable: FDI } \\
\hline const & -0.6172 & 0.30311 & 0.0491 & ** \\
\hline IRcpi & -0.0232 & 0.01036 & 0.0314 & ** \\
\hline $\mathbf{Y}$ & 0.11481 & 0.28651 & 0.6911 & \\
\hline $\mathbf{U}$ & -0.0198 & 0.01019 & 0.0596 & * \\
\hline CPL & -0.4866 & 0.18067 & 0.0107 & ** \\
\hline LOC & 0.00019 & 0.00007 & 0.0123 & ** \\
\hline EU dummy & 0.05349 & 0.02545 & 0.0427 & ** \\
\hline Crisis dummy & -0.0047 & 0.01618 & 0.7712 & \\
\hline \multicolumn{3}{|l|}{$F=2.618332$} & 0.02712 & ** \\
\hline \multicolumn{5}{|c|}{ Adjusted R-squared $=0.157701$} \\
\hline \multicolumn{5}{|l|}{$D-W=1.997394$} \\
\hline \multicolumn{5}{|l|}{ Dependent variable: ER } \\
\hline const & 50.2244 & 3.68153 & $1.9 e-16$ & *** \\
\hline IRcpi & -0.0278 & 0.39642 & 0.9445 & \\
\hline CPL & -34.532 & 5.54400 & $2.4 \mathrm{e}-07$ & $* * *$ \\
\hline EU dummy & -0.9963 & 0.83799 & 0.2417 & \\
\hline Crisis dummy & 1.13823 & 0.64033 & 0.0833 & * \\
\hline \multicolumn{3}{|l|}{$F=13.80491$} & $4.2 e-07$ & *** \\
\hline \multicolumn{5}{|c|}{ Adjusted R-squared = 0.982262} \\
\hline \multicolumn{5}{|l|}{$D-W=1.424572$} \\
\hline
\end{tabular}




\section{Appendix 2}

Regression Results for the Slovak Republic

\begin{tabular}{|c|c|c|c|c|}
\hline C-O estimation (GLS) & Coeff. & S.E. & \multicolumn{2}{|c|}{ p-value } \\
\hline \multicolumn{5}{|c|}{ Dependent variable: Adom } \\
\hline const & -0.0175 & 0.00747 & 0.0248 & ** \\
\hline$(\mathrm{T}-\mathrm{G})$ & 0.53511 & 0.16228 & 0.0022 & *** \\
\hline IRcpi & $-1.6 e-04$ & 0.00014 & 0.2382 & \\
\hline M2cpi & 0.11971 & 0.11775 & 0.3161 & \\
\hline $\mathbf{Y}$ & 0.62708 & 0.11505 & $3.7 e-06$ & *** \\
\hline EU dummy & -0.0008 & 0.00047 & 0.0869 & * \\
\hline EA dummy & 0.00173 & 0.00057 & 0.0047 & *** \\
\hline Crisis dummy & 0.00051 & 0.00036 & 0.1599 & \\
\hline \multicolumn{3}{|l|}{$F=6.558545$} & $05 \mathrm{e}-07$ & *** \\
\hline \multicolumn{5}{|c|}{ Adjusted R-squared = 0.736395} \\
\hline \multicolumn{5}{|l|}{$D-W=2.089714$} \\
\hline \multicolumn{5}{|c|}{ Dependent variable: EX } \\
\hline const & 0.02696 & 0.00975 & 0,0091 & ** \\
\hline ERcpi & $2.4 \mathrm{e}-06$ & $61 \mathrm{e}-06$ & 0.9692 & \\
\hline Yeu & 0.00911 & 0.0009 & $1.3 e-11$ & *** \\
\hline FDlstock, t-1 & 0.20242 & 0.05933 & 0.0017 & *** \\
\hline CPL & 0.00051 & 0.00192 & 0.7918 & \\
\hline LOC & $1.7 \mathrm{e}-06$ & 1.9 e-06 & 0.3750 & \\
\hline EU dummy & 0.00039 & 0.00040 & 0.3453 & \\
\hline EA dummy & -0.0016 & 0.00049 & 0.0022 & *** \\
\hline Crisis dummy & -0.0008 & 0.00029 & 0.0124 & ** \\
\hline \multicolumn{3}{|l|}{$F=40.78281$} & $3 e-15$ & *** \\
\hline \multicolumn{5}{|c|}{ Adjusted R-squared = 0.984867} \\
\hline \multicolumn{5}{|l|}{$D-W=1.797228$} \\
\hline \multicolumn{5}{|c|}{ Dependent variable: IM } \\
\hline const & -0.0057 & 0.00547 & 0.3047 & \\
\hline (T-G) & -0.2328 & 0.18652 & 0.2210 & \\
\hline IRcpi & -0.0002 & 0.00009 & 0.0153 & ** \\
\hline M2cpi & 0.00901 & 0.06116 & 0.8839 & \\
\hline ERcpi & 0.00010 & 0.00005 & 0.0617 & * \\
\hline EX & 1.00965 & 0.08537 & $3 e-13$ & *** \\
\hline CPL & 0.00116 & 0.00125 & 0.3610 & \\
\hline LOC & -0.2343 & 1.04059 & 0.8233 & \\
\hline TF & 0.00463 & 0.00021 & 0.0358 & ** \\
\hline EU dummy & 28.9 e-06 & $2.9 \mathrm{e}-11$ & 0.9214 & \\
\hline EA dummy & -0.0011 & 0.00060 & 0.0877 & * \\
\hline Crisis dummy & 0.00022 & 0.00027 & 0.4346 & \\
\hline \multicolumn{3}{|l|}{$F=463.6662$} & $5 e-32$ & *** \\
\hline \multicolumn{5}{|c|}{ Adjusted R-squared $=0.989240$} \\
\hline \multicolumn{5}{|l|}{$D-W=1.945332$} \\
\hline
\end{tabular}


(Continuation)

\begin{tabular}{|c|c|c|c|c|}
\hline C-O estimation (GLS) & Coeff. & S.E. & \multicolumn{2}{|c|}{ p-value } \\
\hline \multicolumn{5}{|c|}{ Dependent variable: IB } \\
\hline const & 0.00008 & 0.00008 & 0.3193 & \\
\hline FDlstock & -0.0189 & 0.00377 & $1.1 \mathrm{e}-05$ & *** \\
\hline EA dummy & 0.00031 & 0.00011 & 0.0070 & *** \\
\hline \multicolumn{3}{|l|}{$F=12.96506$} & 43 e-06 & *** \\
\hline \multicolumn{5}{|c|}{ Adjusted R-squared $=0.305270$} \\
\hline \multicolumn{5}{|l|}{$D-W=2.000878$} \\
\hline \multicolumn{5}{|c|}{ Dependent variable: FDI } \\
\hline const & -0.0042 & 0.00281 & 0.1429 & \\
\hline IRcpi & 0.00014 & 82.8 e-06 & 0.0919 & * \\
\hline $\mathbf{Y}$ & 0.27705 & 0.15663 & 0.0852 & * \\
\hline U & $62.6 \mathrm{e}-06$ & 74.6 e-06 & 0.4066 & \\
\hline EU dummy & 0.000312 & 0.00051 & 0.5426 & \\
\hline EA dummy & -0.00057 & 0.00040 & 0.1652 & \\
\hline Crisis dummy & 0.000364 & 0.00038 & 0.3399 & \\
\hline \multicolumn{3}{|l|}{$F=2.105081$} & 0.0760 & * \\
\hline \multicolumn{5}{|c|}{ Adjusted R-squared $=0.136859$} \\
\hline \multicolumn{5}{|l|}{$D-W=2.041257$} \\
\hline \multicolumn{5}{|c|}{ Dependent variable: ER } \\
\hline const & 13.067 & 9.6603 & 0.184 & \\
\hline IRcpi & 0.3230 & 0.2655 & 0.231 & \\
\hline CPL & -8.162 & 4.8913 & 0.103 & \\
\hline EU dummy & 0.6635 & 1.0974 & 0.549 & \\
\hline EA dummy & 0.3244 & 1.0470 & 0.758 & \\
\hline Crisis dummy & 0.0164 & 0.7260 & 0.982 & \\
\hline \multicolumn{3}{|l|}{$F=0.940022$} & 0.466 & \\
\hline \multicolumn{5}{|c|}{ Adjusted R-squared = 0.992065} \\
\hline \multicolumn{5}{|l|}{$D-W=1.384419$} \\
\hline
\end{tabular}




\section{References:}

Arlt, J. (1997), "Regresní analýza nestacionárních ekonomických časových řad“. Politická ekonomie, Vol. 45, No. 2, pp. 281-289.

Black, J. (2003), Oxford Economic Dictionary. Oxford: Oxford University Press.

Bolotov, I. (2011), "L'équilibre interne des nouveaux Etatsmembres de l'UEmettant l'accentsur la crisemondiale," in Trends in International Business. Lyon: Université Jean Moulin Lyon 3, pp. 133-149.

Cajka, R. (2010a), "Problem of Nominal and Real Convergence - Should Maastricht Convergence Criteria Be Changed," in Trendy v mezinárodním podnikání. Prague: Nakladatelství Oeconomica, 2010, pp. 49-68.

Cajka, R. (2010b),"Single European Currency Experience of New Member States of the European Union - Problem of Nominal and Real Convergence". International Trade and Finance Association Conference Papers. 20th International Conference Working Papers. Working Paper No. 3.

Cajka, R. (2010c), "Srovnání dopadů probíhající ekonomické krize na Českou republiku a Slovensko," in Taušer, J., Krajčík, D., eds. Česká republika a Slovensko v mezinárodním obchodě a podnikání. Vliv finanční krize na mezinárodní podnikání. Praha: Nakladatelství Oeconomica, 2010, pp. 205-212.

Cajka, R., Gajduskova, K., Bolotov, I. (2011), "Comparison of Impact of the Economic Crisis and Anti-Crisis Measures on the Czech Republic and Slovakia." Management \&Gouvernance, Vol. 4, pp. 79-92.

Cerna, I. (2011). "What Factors Determined FDI Inflow into Czech Republic in Past Decade? Territorial Analysis," in Krajcik, D., Tauser, J., eds., Česko a Slovensko v medzinárodnom obchode a podnikaní. Bratislava: Ekonomická univerzita, pp. 30-34.

Chow, G. C., Lin, A. (1971), "Best Linear Unbiased Interpolation, Distribution and Extrapolation of Time Series by Related Series." The Review of Economics and Statistics, Vol. 53, No. 4, pp. 372-375.

Coudert, V., Pouvelle, C. (2010), "Assessing the Sustainability of Credit Growth: The case of Central and Eastern European Countries." The European Journal of Comparative Economics, Vol. 7, No. 1, pp. 87-120.

Dougherty, C., Introduction to Econometrics Third Edition. Oxford: Oxford University Press, 2006.

Engle, R., Granger, C. W. J. (1987), "Co-Integration and Error Correction: Representation, Estimation, and Testing." Econometrica, Vol. 55, No. 2, pp. 251-276.

Eurostat, GDP per capita in PPS, European Union.

Eurostat, Harmonized unemployment rate, European Union.

Gajduskova, K. (2010a), "Vnější rovnováha nových členských států EU," in Trendy v mezinárodním podnikání. Prague: Nakladatelství Oeconomica, pp. 69-83.

Gajduskova, K. (2010b), "Dopad světové ekonomické krize na přímé zahraniční investice v zemích střední a jihovýchodní Evropy". Working Papers Fakulty mezinárodních vztahů, Vol. IV, No. 20.

Ghosh, I. (2007), "The Relation between Trade and FDI in Developing Countries - A Panel Data Approach." Global Economy Journal, Vol. 7, No. 3, pp. 1-32.

Guttman, S., Richards, A. J. (2004), "Trade Openness: An Australian Perspective." Australian Economic Papers, Vol. 45, No. 3.

Havrlant, D., Husek, R. (2011), "Models of Factors Driving the Czech Export." Prague Economic Papers, Vol. 20, No. 3, pp. 195-215.

Hsing, Y. (2005), "Analysis of Exchange Rate Fluctuations for Slovakia: Application of an Extended Mundell-Fleming Model." Applied Financial Economics Letters, Vol. 1, pp. 289-292. 
Jankovic, E. M., Yatrakis, P. G. (2011), "The Financial Setting for FDI Inflows into the Czech Republic and Slovakia." International Business Research, Vol. 4, No. 3.

Kral, P. (2004), "Identification and Measurement of Relationships Concerning Inflow of FDI: The Case of the Czech Republic." CNB Working Papers Series, No. 5.

Lazovy, P., Slovakova, V. (2009), "Dopady súčasnej globálnej krízy na ekonomiky krajín východnej Európy," in Krajcik, D., Tauser, J., eds., Česko a Slovensko v medzinárodnom obchode a podnikaní. Bratislava: Ekonomická univerzita, pp. 34-42.

Mandel, M. (2000), "Efektivní tržní klasifikace: model a aplikace." Finance a úvěr, Vol. 50, No. 9, pp. 452-463.

Mandel, M., Tomšík, V. (2001), "Mix monetární a fiskální politiky v České republice: Empriciká verifikace modelu efektivní tržní klasifikace." Politická ekonomie, Vol. 49, No. 2, pp. 163-176.

Mandel, M., Tomšík, V. (2003), Monetární ekonomie v malé otevřené ekonomice. Prague: Management Press.

Mundell, R. A. (1962), "The Appropriate Use of Monetary and Fiscal Policy under Fixed Exchange Rate." IMF Staff Papers, Vol. 9, pp. 70-79.

Mundell, R. A. (1968), International Economics. New York: Macmillan.

OECD (2010), OECD Factbook 2010: Economic, Environmental and Social Statistics, OECD Publishing.

Pilbeam, K. (2006), International Finance, 3rd ed. Houndmills, Basingstoke, Hampshire and New York: Palgrave Macmillan.

PIchova, B. (2006), Zahraniční ekonomické vztahy České republiky, 2nd ed. Prague: Nakladatelství Oeconomica.

Radvansky, M. (2010), "Strednodobá prognóza vývoja ekonomiky SR v rokoch 2009-2013." Profini, February 12, 2010.

Singer, M. (2010), “Hospodářská krize a česká ekonomika”. Lecture at the Canadian Commercial Council in Ostrava.

Tomšík, V. (2000), Vyrovnávací procesy platební bilance a analýza vývoje zahraničního obchodu České republiky v létech 1993-1998. Národohospodářský ústav Josefa Hlávky Study No. $1 / 2000$.

Vagac, L., Palenik, V. et al (2001a), "Sectoral Analysis of the Slovak Foreign Trade." Center for Economic Development, Institute of Slovak and World Economics of the Slovak Academy of Sciences.

Vagac, L., Palenik, V. et al (2001b), "Trade Effects of EU Integration: The Case of the Slovak Republic." Center for Economic Development, Institute of Slovak and World Economics of the Slovak Academy of Sciences. 